\title{
As notícias sobre corrupção e as redes de sociabilidade: um estudo exploratório em Portugal, Brasil e Angola
}

\section{News on corruption and sociability networks: an exploratory study about Portugal, Brazil and Angola}

\author{
Isabel Ferin Cunha*, Bruno Araújo** \\ * Professora Associada da Universidade de Coimbra, Portugal \\ ** Professor Auxiliar da Faculdade de Comunicação e Artes da Universidade Federal de Mato Grosso, Brasil
}

Resumo

\begin{abstract}
O estudo exploratório que apresentamos neste texto é resultado da análise qualitativa de cinco notícias sobre casos de corrupção em Portugal e no Brasil, que foram interrelacionados pela investigação judiciária, com desdobramentos em Angola, um país africano de língua portuguesa. A cobertura jornalística e a mediatização desta problemática foram investigadas num projecto desenvolvido em Portugal e no Brasil entre 2012 e 2015. Neste artigo, pretendemos analisar: como as redes de sociabilidade são descritas nos textos e na infografia que o acompanha; como os relacionamentos entre instituições e atores do Espaço Lusófono são desenhados na notícia e em sua infografia; a articulação entre cobertura de notícias e infografia (Gray, Chambers and Bounegru, 2012). Assumimos que os infográficos que acompanham o texto jornalístico são dispositivos para a mediatização da corrupção e da política (Stromback, 2008; Hepp, 2012). Portugal, Brasil e Angola integram o Espaço Lusófono, um espaço regional dentro da globalização, com raízes históricas no império colonial português, caracterizado pela partilha de línguas e a proximidade cultural (Straubhaar, 1991; Davis, Straubhaar, Cunha, 2016).
\end{abstract}

Palavras-chave: Redes de sociabilidade, mediatização da corrupção, Espaço Lusófono, infográficos

Abstract

\begin{abstract}
The exploratory study we present is the result of the analysis of five news reports on corruption cases in Portugal and Brazil, with developments in Angola, a Portuguese speaking African country. The journalistic coverage and the mediatization of this issue were investigated in a project developed in Portugal and Brazil between 2012 and 2015. In this paper, we aim to analyze: how the networks of sociability are described in the texts and accompanying infographics; how the relationships between institutions and actors of the Lusophone space are presented in the news and in its infographics; the articulation between news coverage and infographics (Gray, Chambers and Bounegru, 2012); and infographics as devices for the mediatization of corruption and politics (Stromback, 2008; Hepp, 2012). Portugal, Brazil and Angola integrate the Lusophone space, a regional space within globalization, with historical roots in the Portuguese colonial empire, characterized by the sharing of a common language and by cultural proximity (Straubhaar, 1991; Davis, Straubhaar, Cunha, 2016).

Keywords: Sociability networks, mediatization of corruption, Lusophone space, infographics.
\end{abstract}

\section{Introduction}

Between 2012 and 2015, the Center for Media Research and Journalism at the New University of Lisbon developed a project on the journalistic coverage of political corruption in Portugal, Brazil and Mozambique. Throughout the execution of the project, we analysed a great number of news in the press, both on paper and online, as well as in television, which described those phenomena making use of the idea of network. The news constructed the phenomena of corruption as a network, interrelating actors and institutions of countries which speak Portuguese, adding infographics, illustrations and other graphics with the same 
network appearance. This raised a number of questions. How are sociability networks of corruption described in the press and what relationships do they establish with the infographics which accompany the news? What relationships are drawn between actors and institutions of the Portuguese-speaking world? In what way does the description of network relations and the utilization of infographics constitute a kind of mediatization devices?

The paper aims to reflect on the presentation of corruption as a network in the news, based on an exploratory study of five news stories from five periodicals from three Portuguese-speaking countries (Brazil, Angola and Portugal). It also intends to observe the relations between actors and institutions, as drawn in this news and its infographics. This article also tries to understand the role of these procedures as a factor of mediatization, in the sense of involving the logic of visibility and the processes of signification made by the media.

The selection of newspapers, printed and online, took into account the circulation and audience in each country. The choice of the five news items followed these criteria: 1) they were published in printed or online media of great circulation and audience; 2) they focused on the cases of corruption with greater visibility in those countries, namely the cases Marquês (Portugal) e Lava-Jato (Brazil); 3) they consisted of text and infographics; 4) they described, in the form of a network, public and private institutions and actors from the three countries which belong to the Lusophone space. We must emphasize that these countries share a historical and cultural space, originating from the geographic area of the former Portuguese empire. Despite colonization, wars and historical conflicts, these countries have maintained a dense population and economic and cultural ties throughout the centuries. We also point out that the production and sharing of news, books, theater, music, news and soap operas constitute, since the seventies of the last century, elements which generate proximity between these countries (Strauhbaar, 2001; Davis, Strauhbaar and Cunha, 2016).

This exploratory study thereby focuses on news published in printed and online media of Angola (Folha\&), Brazil (Portal G1.com and Estado de São Paulo) and Portugal (Observador and Semanário Sol). They report cases of corruption with high social visibility in the form of a network, and they include infographics. We would like to point out that Semanário Sol was bought by the Angolan owned Newshold group, and the news site $O$ Observador, although considered an independent newspaper, maintains relations with rightwing political and economic circles in Portugal. In Brazil, the newspaper O Estado de S. Paulo and the G1.com news site, from which the empirical material for this exploratory study was extracted, belong respectively to Grupo Estadão and Grupo Globo, family-owned media groups which are also two of the five largest in Brazil. In Angola, Folha 8 is an independent Angolan newspaper, which has opposed the dictatorial regime and is supported by the German Konrad Adenauer Foundation. 
The cases which we identified as having a high social visibility are, in alphabetical order: BES ${ }^{1}$, Lava Jato², Marquês ${ }^{3}$ and Mensalão ${ }^{4}$. According to the ongoing legal investigations, these cases are interconnected. Their processes drag on in courts and have been covered by the media (press, television, radio, social networks) for many years. They have ramifications and interrelationships between them, connecting interests and actors of different nationalities, irrespective of the country where the crime was initially identified. These cases cover the governance contexts of the Workers' Party (PT) in Brazil, but also involve the Brazilian Democratic Movement Party (PMDB) and the Brazilian Social Democracy Party (PSDB), the Socialist Party (PS) and the Social Democratic Party (PSD) in Portugal, and the autocratic government of Angola, chaired by President José Eduardo dos Santos of the Popular Movement for the Liberation of Angola (MPLA), in office since 1979.

The objective of this paper is the exploratory description and analysis of journalistic materials (text and infographics). It attempts to understand how the political, economic and business interests involved are presented, the nature of the reported sociability of the various actors, and the number, dimension and role of the implicated institutions, as well their network representations in the news (text and infographics). It also aims to understand how this strategy confers visibility to the relations described above.

\section{Political and media contexts}

Insofar as our focus is the news about corruption involving politicians in Brazil, Portugal and Angola, we proceed to briefly describe the political and media systems of these three countries.

The Portuguese political system is semi-presidential and parliamentary, with an executive chaired by a Prime Minister. Presidential elections take place every five years and legislative elections are held every four years. To these democratic acts are added the elections to the European Parliament. Voting is not compulsory and the percentage of voters is currently between $45 \%$ and $55 \%$ of the voters registered in the electoral rolls (Freire, 2016). The financing of political parties and electoral campaigns is guaranteed by public subsidy and audited by the Constitutional Court. Since the end of the dictatorship, on April 25, 1974, the country has been governed by two parties, the Socialist Party (PS) and the Social Democratic Party (PSD), which

\footnotetext{
${ }^{1}$ Banco Espírito Santo (BES), a private bank founded in 1836 which has coexisted with the various Portuguese political regimes ever since. In 2013, losses above EUR 95 billion and irregularities in the accounts were disclosed. In July 2014 the president, banker Ricardo Salgado, was replaced by a president appointed by the government. The BES license was canceled and the Novo Banco created. Thousands of shareholders were hampered by the separation between a good bank (Novo Banco) and bad bank (toxic assets and debt).

2 The Lava Jato case, ongoing in Brazil, began with the investigation of a scheme of fraud and misappropriation of the state-owned company Petrobras for the illegal financing of political parties and politicians. According to the federal police and the courts, company directors appointed by political parties favored several builders through huge over-invoiced contracts. The scheme benefited politicians, parties and individuals involved.

${ }^{3}$ The Marquês case, which is still ongoing, is an investigation of an alleged scheme of corruption, money laundering and influence peddling, involving former Socialist Prime Minister José Sócrates, as well as the banker Ricardo Salgado (BES), a CO of Portuguese companies with state participation. At the center of the investigation are the 23 million euros collected in Switzerland in accounts of a businessman and friend of the former Prime Minister, Carlos Santos Silva, transferred to Portugal between 2004 and 2011.

${ }^{4}$ The Mensalão scandal emerged in 2005 and involved construction companies and Brazilian politicians, among them members of the Partido dos Trabalhadores, PT (Workers' Party). The builders were accused of paying money to deputies from various political parties, to finance parties and politicians in return for favoritism in business.
} 
alternated in power with occasional alliances with other party formations, Party of the Social Democratic Center (CDS-PP), the Portuguese Communist Party (PCP) and, more recently, the Left Bloc (BE).

Brazil is a federation of 26 states and a federal district whose political system is presidential. The President of the Republic combines the functions of head of government and head of state. Voting is compulsory and voters are called to vote every two years to elect representatives for four-year terms in general and municipal elections. At the federal level, the general elections involve the President of the Republic, federal deputies and senators; at the state level, state governors and state deputies. The municipal elections aim to elect the mayors and councilors of the 5,570 municipalities of the country. The financing of the campaigns has historically been carried out by the private sector, especially by large companies, namely state-owned or with declared interests in public works, but this was banned in 2015 by the Federal Supreme Court.

The Brazilian political system is multiparty, and there are now 35 parties, according to the Electoral Court. Despite partisan dispersion, federal government has been disputed by two parties over the last twenty years, the PSDB and the PT, center-right and center-left parties, respectively. In the government, in addition to joining smaller parties, the PT and the PSDB made alliances with the PMDB, which occupies the center of the party spectrum.

Angola officially became a multiparty republic in 1991 and, after passing a constitution in 1992, held elections to elect a President and a Legislative Assembly that same year. The result of this democratic act granted the single-party, the Popular Movement for the Liberation of Angola (MPLA), the legislative majority, although the president José Eduardo dos Santos, of the same party, was not elected in the first round. Angola endured a long civil war which ended with the death of the leader of the largest opposition party (UNITA). The parliamentary elections were then postponed until 2008, when the MPLA secured a majority in parliament but failed to re-elect President José Eduardo dos Santos. In 2010 the constitution was changed, maintaining the rules for the parliamentary elections, but giving the most voted party the power to elect the President, who to this day is José Eduardo dos Santos. In Portugal and Brazil, justice is, constitutionally, independent from the political power, but this autonomy tends to be conditioned by it in different degrees. In Angola, justice is entirely subordinate to the president's dictatorial power.

The characteristics of each country's national and political culture directly influence how elites relate to res publica (Blankenburg, 2002; Johnston, 2005) and, therefore, the type of corruption. Corruption also depends on the economic and political pressures, not only national but also international, within the context of the globalized market. Therefore, a single scale of corruption applicable to all countries cannot be applied, since each country will have its own cultural specificity, with different degrees of democracy and transparency of political and social institutions, and a different capacity and availability of citizen participation and mobilization. Moreover, according to the liberal focus of these authors, the characterization of corruption depends on the degree of markets openness, but also on the mechanisms for its regulation.

From this liberal point of view, Johnston (2005) proposes four major categories for the observation of corruption, identified as follows: Influence Markets, Elite Cartels, Oligarchs and Clans, and Official Moguls. This typology, based on the inevitability of a growing globalized economy, is founded on the credibility of public and private institutions according to the type of governance, as well as on the opportunities for participation and well-being offered to citizens by open market societies. In light of this proposal, we could situate Portugal at a stage where it accumulates indicators inherent to both the Elite Cartels and to the Influence Markets. This period is characterized by the fact that public institutions are under great pressure 
from the international financial markets, which forces national elites to change their accumulation strategies. The same proposal places Brazil in a phase where we can find overlapping elements inherent to the characteristics identified in the syndromes called Oligarchs and Clans and Elite Cartels, as well as Influence Markets. In this amalgam of tensions, public and private institutions are highly discredited and citizens tend to exert pressure (mainly on the streets) demanding their regeneration. In Angola, we identify the indicators of Oligarchs and Clans, particularly in the behavior of political elites who benefit from the advantages offered by global markets, keeping more than $90 \%$ of the population in a deficit of citizenship, participation and consumption.

The media systems of these countries also present different genealogies: In Portugal, there exists a public sector and a private sector; In Brazil, the private sector is hegemonic and there exists a small public sector; In Angola, a public sector controlled by the government of President Eduardo dos Santos predominates and the private sector is conditioned to the interests of the ruling party and its representatives.

As in most European countries, the media system in Portugal emerges from a structuring public sector, although it also includes private activity since its foundation. The Salazar dictatorship (1933-1974) directly influenced media activity, with all its censorship and governmental control, but allowed private operators identified with the regime. Portugal's accession to the European Union (1986) had consequences for the liberalization and deregulation of the Portuguese media system, namely the privatization of a large part of the press and radio and the end of the state television monopoly (RTP), as well as the emergence of private televisions in 1992/93 (SIC and TVI). In the new millennium, the Portuguese media system acquired new configurations due to the entry of foreign capital, namely Angolan and, since 2016, Chinese. Among subscription television channels are the Brazilian Rede Globo (owned by the Marinho family) and Record (owned by the Brazilian Universal Church of the Kingdom of God), attracting large audiences.

The Brazilian media system has, since its origin, a strong and dynamic private sector which subsisted during the dictatorship and military regimes. This is the case of TV Globo, from Grupo Globo, owned by the Marinho family, which as of 1965 raised a media group in Latin America consisting of television channels, print newspapers, news agencies, radio stations and internet portals, but also film, publishing and music industry. Other main media conglomerates in the country are held by family groups: Grupo Folha, from the Frias family; O Estadão, from the Mesquita family; or Editora Abril, from the Civita family. We also highlight two other characteristics of the Brazilian media system: the weight of religious organizations and the direct involvement of politicians in television stations.

In Angola, there exists a public sector dominated by the ruling party, which, through the Jornal de Angola, the Public Television of Angola (TPA) and the National Radio of Angola and its affiliates, constitute the official voice of the Angolan presidency. The private sector is controlled by the Angolan nomenklatura (generals and relatives of the president-in-office), for example, TV Zimbo, Producer Semba and satellite TV operator Zap. Other groups such as TRP, Impresa and Africa TVI, of Portuguese nationality, and Brazilian groups like Globo and Record, have interests and products targeted to the Angolan Media market. We also emphasize the presence of the Catholic Church on radio, based on Radio Ecclesia, and the role of Folha 8 , an independent newspaper supported by the German Konrad Adenauer Foundation. 


\section{The construction of networks as a mediatization strategy in the press}

The idea of mediatization has been recovered in the last decade, mainly in Europe, by a group of researchers who attribute to the media a crucial role in globalized societies (Stromback, 2011, Hepp, 2012, Couldry and Hepp, Levingstone and Lunt, 2014). This perspective, which should not be confused with mediacentrism, considers that social institutions are more and more subordinated to media logics, especially those of television, and to the mastery of the image over the text (written or oral). These logics involve the essence of the know-how of the media, such as formats, content, editing, layout, graphics and infographics, as well as rhythms and discourses which tend to shape, in a cumulative way, in the medium and long term, the citizens' understanding and knowledge of the world.

We analyze in five news items how, in different degrees, facts and events are interpreted and relationships are established between actors, individuals or groups. These news items also describe the roles and objectives of these actors, who are mainly high dignitaries of democracy, as well as advance hypotheses for the interpretation of situations or events. At the same time, these news items use infographics as a way of outlining the knowledge about the reported phenomena and events. The infographics arise to fix perceptions of relationships between elements, by relating them to each other in a network, and are an imagistic tool to suggest and conduct readings. For many journalists and academics, infographics is not only a way to make the information appealing, but also a way to present contextualized and complex information, although they admit that its reading involves sophisticated literacy skills (Gray, Chambers and Bounegru, 2012). On the other hand, as suggested in the studies on the mediatization of politics (Stromback, 2011), the description and network representation of corruption phenomena in texts and infographics constitute a contribution to the consolidation of "knowledge" and the construction of a "public opinion" on corruption and democracy.

It is also important to clarify what we mean by network interrelationships. The concept of social network aims to describe sociabilities and interests among individuals, social groups and institutions, with the purpose of establishing connections between actors and identifying the circuits of information transmission and the exchange of "interests". Not all social relationships are pre-established and, for this reason, contacts can occur occasionally and unpredictably. Moreover, the relationships between network elements can be symmetrical or asymmetrical. The first are characterized by the balance between participants and the information made available. The second, by being mainly centered on an actor whose function is to control not only the information, but also its quality. From this position of asymmetry of the actors in the networks, highly complex relations take place between them, characterized by the constitution of strong and weak ties and by the emergence of positions of domination, subservience or isolation. Actors can also create smaller nodes or subgroups within an integral network (Mercklé, 2004, Lemieux and Ouimet, 2008).

In fact, the idea of network has been very present in the journalistic coverage of corruption phenomena, both in Portugal and in Brazil. The news describing corruption emphasize interpersonal relationships, acquaintances, friendships, scheduled meetings and scenarios which frame the circles of power within a chain of relations guided by economic, political or personal goals. In the journalistic coverage of corruption, the structures of interpersonal communication are described and defined after the identification of the actors, their functions and positions in the network and the links which they establish among themselves. In this context, the actors function as nodes. 
The networks built in the news about corruption are also materialized in infographics in which the nodes (singular actors or institutions) and the arcs (links) suggest specific readings due to the visibility given to the graphic elements. These networks can focus on individuals (eg. politicians, bankers, businessmen, civil servants), but also on institutions (eg. state enterprises, public or private enterprises), show inner cores (eg. in countries or companies) and external centers of corruption (in countries and companies). The links which relate the actors point to relationships of power and complicity and configure plots to achieve certain goals. Based on the evaluation of the density of connections, we can also observe the power circles and national interests, as well as their relations with international interests, generally linked to the interests of the Portuguese-speaking countries economy. In this last perspective, it is also possible to map influence peddling, an activity which emerges mainly from cultural / social capital legitimately acquired in governmental and / or institutional functions, but which is diverted or used to one's own advantage, partially or totality, often under the cover of the so-called economic diplomacy (Zaharna, Arsenault and Fisher, 2013). In the following analysis of the news and infographics we will identify the actors - especially those who constitute the nodes - and their functions, the quality of the referenced links - also considered arcs - as well as the proposed motivations.

\section{Exploratory analysis of news: texts and infographics}

The first news item which we describe and analyze, accompanied by infographics, was published on July 24, 2015, in Semanário Sol, with the title "Brazilian scheme arrived in Portugal by diplomatic bag" (Teia do Brasil chegou a Portugal por mala diplomática) (Figure 1). Signed by Carlos Diogo Santos, the text seeks to summarize the various relations between the cases Lava Jato and Marquês, and is organized according to the lead: "Brazil has sent Lisbon a request for international aid in the context of the largest money laundering in that country's history - Lava Jato. The letter rogatory sent to the Attorney General's Office (PGR) officialized what has long been known: the mega-processes of the two countries are interconnected". And the following subtitles: "What connects Lava Jato to Portugal?", "Lava Jato crosses Portugal in the week when the Court of Appeal once again refuses the release of Socrates from the Évora prison"; "What is the link between the Operation Marquês and Brazil?"; "What the Lava Jato is."

The news emphasizes the direct interconnections of the investigations in both countries, having in its center the Odebrecht company, which is involved in the Lava Jato case in Brazil, and its associates in Portugal (Bento Pedroso Construções and Grupo Lena). These companies were part of a construction consortium (Elos consortium) in Portugal for high-speed rail and a hydroelectric dam. The corruption scheme in Brazil, investigated in the Lava Jato case, centered on the state-owned oil company Petrobras, involved bribes paid to managers of the Brazilian oil company by a Portuguese bank - later intervened by the Portuguese State $(B A N I F)^{5}$ - as well as by Brazilian construction companies and Portuguese telecommunications companies. It should be noted that this process included influence peddling, money laundering and crimes against the

\footnotetext{
${ }^{5}$ BANIF (Banco Internacional do Funchal): In December 2015, BANIF was intervened by the Portuguese State. Under this process, its good quality assets were sold to the Spanish Bank Santander Totta. The business involved a total of $€ 2.25$ billion in public support, of which $€ 1.766$ billion covered directly by the state.
} 
state. The description is centered, respectively, on the former Portuguese Socialist Prime Minister José Sócrates and on the former president of Brazil Luís Inácio Lula da Silva of the Workers' Party (PT). Also noteworthy is the involvement of ex-ministers, administrators of private companies (constructors and a pharmaceutical company) and Portuguese and Brazilian state companies, as well as offshores and two Portuguese banks which collapsed between 2014 and 2015 (BANIF and BES).

The arcs (links) which aggregate the nodes (actors) described in the weekly Semanário Sol news can be synthesized into four main categories (Mercklé, 2004; Lemieux and Ouimet, 2008): The "motivations" category, which highlights the interest of those involved in the accumulation of political, economic and social capital; The category "connection", which identifies similarities and differences between actors and institutions; the category "density", which maps the quality of the relations between actors and institutions and, finally, the "cohesion" category, which describes the structure and objectives of the groups. The text is balanced and it has a generally neutral tone, although it sometimes uses some irony, in the way it describes the involvement of political agents, namely the former Portuguese prime minister and the former Brazilian president, as well as the performance of the Portuguese and Brazilian public and private companies. The infographics which accompany the text show the half-body photo of the former Portuguese Prime Minister José Sócrates on the right and, on the left, the half-body photo of the former president of Brazil, Lula da Silva. The illustration, in the form of a network, is colored and aims to represent the links between the cases Marquês (Portugal) and Lava Jato (Brazil). The central element is a node - a photograph of the two smiling politicians - where connections converge. The network is graphically constructed around the central node, including ten more nodes, three of which are represented by the faces of political agents who were already accused in the cases in Portugal and Brazil, and seven other nodes, identified by the names of the companies involved. The illustration is accompanied by captions explaining the roles of actors (political agents and companies), the actions undertaken by them and the roles played in the reported cases.

Figure 1: Representation of the cases Marquês (Portugal) and Lava Jato (Brazil) in the weekly Semanário Sol(July 2015)

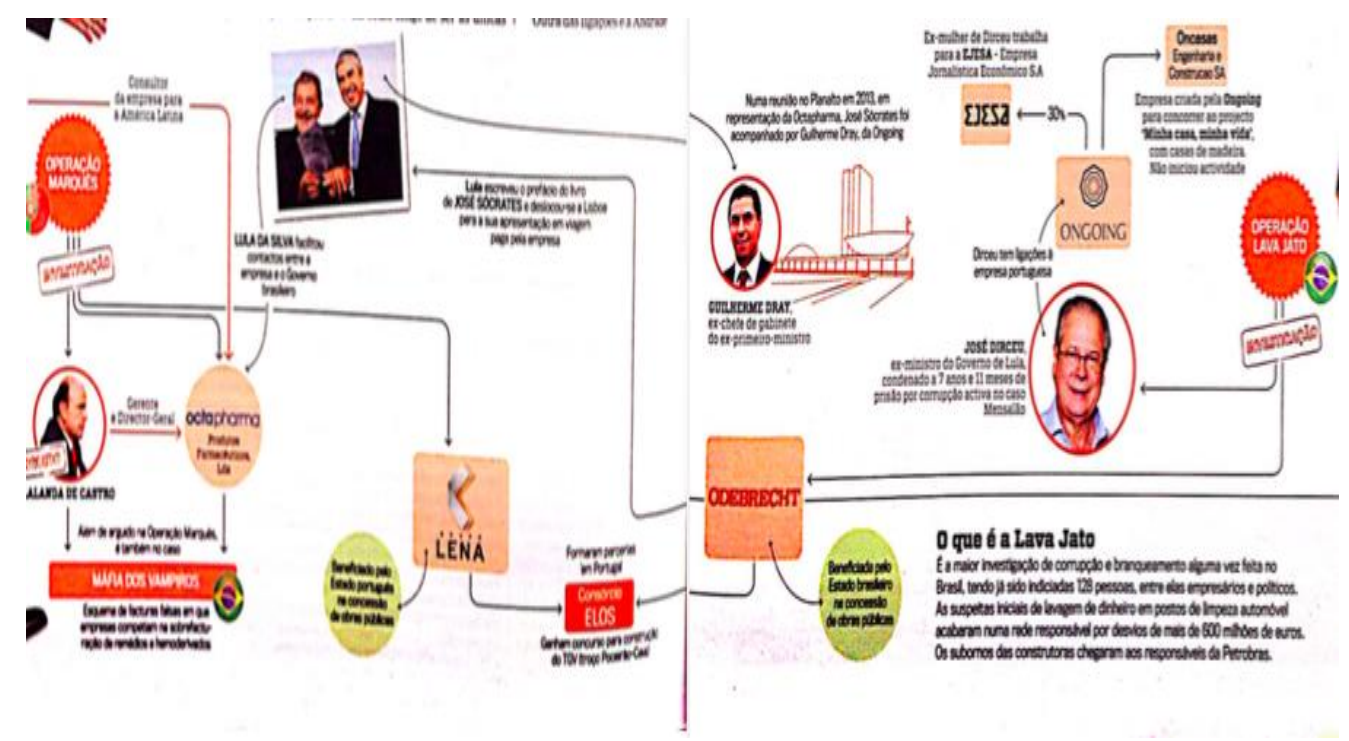


Not all the links established in the journalistic text between Portuguese and Brazilian agents and companies are present in the infographics, namely those which relate a former socialist minister (Armando Vara ${ }^{6}$ ) to the branch of the Brazilian construction company Camargo Correa in Africa, with interests in Angola. Similarly, there is no reference in the illustration to the intervened Portuguese banks (BANIF and BES) and the meeting which allegedly took place between the former Brazilian president and the then Portuguese Prime Minister, Passos Coelho, of the Social Democratic Party (PSD), to facilitate the participation of a Brazilian company in the purchase of a Portuguese state-owned company.Therefore, the illustration omits data and highlights the political actors in the central node, namely the former Portuguese Socialist Prime Minister and the former president of Brazil, portrayed as "influential traffickers" and informal "lobbyists", favouring market interests.

It is important to note the centrality assumed by the former president of Brazil (Lula da Silva) and the former Portuguese prime-minister (José Sócrates), which indicates the effectiveness of networks of political sociability in the Lusophone Space and the contexts and practices which these relations provide. The illustration places them in the position of promoters and intermediaries of economic interests of companies which would have advantages in relying on the political potential of both to secure their business in the Portuguese speaking countries. In this sense, the relationships represented in this infographic indicate the involvement of political and business actors in sociabilities or plots constituted by allegedly illegal practices. All these evidences, namely the influence peddling, point out to a scenario of negotiations between companies operating in the Lusophone Space to acquire a larger dimension in a hegemonic Anglo-Saxon globalization.

In the Portuguese online newspaper O Observador", this news item is inserted in the section "Justice", under the title: "Lava Jato in 5 graphs. How the Brazilian case crosses several processes in Portugal", followed by the lead "Operations Marquês, Monte Branco, BPN ${ }^{8}$. The Brazilian scandal crossed several national processes. 5 graphics to understand the web of connections which the PGR (Attorney General of the Republic) will help to investigate". Then comes a photograph of former President Luiz Inácio Lula da Silva over the caption: "The former Brazilian president, Lula da Silva, is suspected of influence peddling in an international commercial transaction within the Lava Jato process". The news is signed by Maria Catarina Nunes (Portuguese author of the text) and Milton Cappelletti (Brazilian author of the infographics).

The subtitles of this news piece are "Lula da Silva's journeys", "Lula da Silva and the conversations with Passos Coelho", "Operation Monte Branco and Case BPN", "Operation Marquês and Armando Vara", "TGV9 and Operation Marquês". They are accompanied by infographics illustrating the facts and relationships described in each of the five subheadings, which are referred to as: "A web of relations between companies

\footnotetext{
${ }^{6}$ Armando Vara: former minister, friend of prime-minister José Sócrates, former manager of Caixa Geral de Depósitos, the Portuguese public bank, former vice-president of Banco Comercial Português, a private Bank, convicted in another corruption case, Face Oculta (Hidden Face).

${ }^{7}$ http:/observador.pt/2015/07/21/lava-jato-5-graficos-caso-brasileiro-cruza-varios-processos-portugal/

${ }^{8}$ These are the names of corruption cases that are under investigation in Portugal. The former prime minister of Portugal is a defendant in the first two. The last case, BPN (Banco Português de Negócios), which resulted in the collapse of the bank, is allegedly related to the Monte Branco case.

${ }^{9}$ TGV - High Speed Rail
} 
and people which O Observador tried to simplify in 5 infographics". In this exploratory work, we will analyze the whole of the news item, but only focus, for reasons of space, on the first infographics (Figure 2).

The text points out that business between Brazil and Portugal has grown visibly in recent years, promoted by the former Brazilian president Lula da Silva, who "valued the connections with Portugal". The article shows that the cases of corruption investigated in Brazil, with developments in Switzerland and Africa, had repercussions in Portugal, given the close relations between actors and institutions. The names of those involved and defendants in Portugal, such as the former Portuguese Prime Minister, José Sócrates, and the former Socialist Party minister and former administrator of the public bank Caixa Geral de Depósitos (CGD), Armando Vara, are cited. It is mentioned that the money was handled by a wealth management company (Akoya) and a bank (BPN), and which bankers were involved in this case (Ricardo Salgado, bank BES, and Oliveira e Costa, BPN bank). It is pointed out that, in Brazil, the construction company Odebrecht is "at the center of one of the largest corruption networks in Brazil, known as Operation Lava Jato". It is also mentioned that the president of the construction company Andrade Gutierrez and others, who were involved in businesses between the Portuguese telecommunications company PT SGPS and the Brazilian Oi, were also arrested.

The five infographics which accompany the news article are intended to "tell" or "show", graphically and visually, the relationship between the different referenced actors. The first infographics, which we will analyze next, is entitled, like the subtitle "The Lula da Silva trips" (Figure 2). The construction company, Odebrecht (which is shown in red), is presented as a central actor. The infographics show two figures representing the former President: one on the top and one on the bottom right, both of them functioning as actor nodes. From the first node above, three black arrows (links) connect it to three places (Cuba, Africa and Portugal), where the actor (former Brazilian President) was supposed to have used his relational capital in favor of the Odebrecht company. A red arrow links this company (node and central actor) to the former Brazilian President (the node on the bottom right) with the caption "paid Lula 6 trips to Portugal, one of them to present the book of Sócrates". From the same node / actor, a black arrow with the caption "interceded" points to the Brazilian National Bank for Economic and Social Development (BNDES) and, finally, a red arrow with the caption "funded contracts" points back to Odebrecht (the central node).

Figure 2: "Lula da Silva's trips" in O Observador (July 2015)

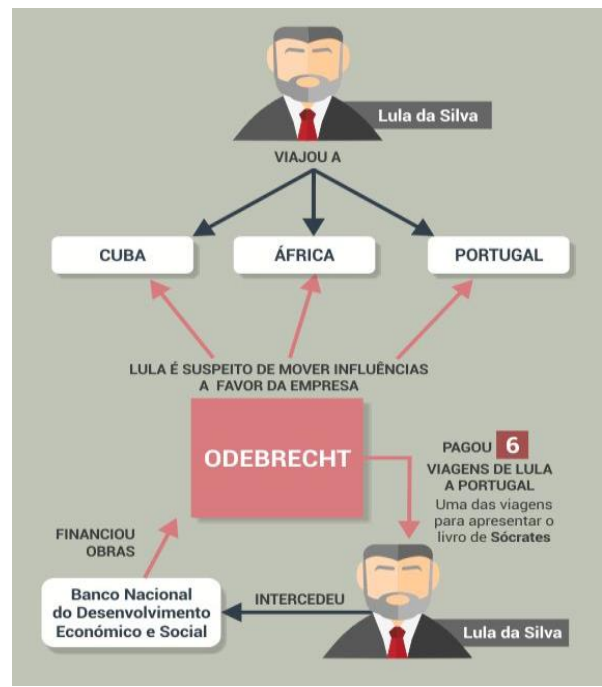


This infographic (Figure 2) presents the lobby around the actor, former president Lula da Silva, and his political travels. The image suggests eventual "influence peddling in an international transaction", namely within economic diplomacy. It is well known that economic diplomacy relies more and more on the economic and relational capital of former politicians, but the illegality of this transaction lies in the compensation eventually paid by the company. In the infographics, the trips made by the former President to Portugal are still present but, besides the presentation of the book, the motivations of these trips are left unclear, and only referred to as "meetings in Lisbon with Brazilian entrepreneurs linked to that construction company". In the texts which follow the subtitles, as well as in the infographics which illustrate them, the interests of the construction company Odebrecht (always a central node / actor) are given great prominence, although the political actors also have great visibility, former Brazilian president and former prime ministers of Portugal (Passos Coelho and José Sócrates). Under the subtitle "Lula da Silva and the conversations with Passos Coelho", the episodes of the purchases and sales of a Portuguese company (EGF) are reported. In this process, the former Brazilian President would have acted as an intermediary, apparently without success, counting "with the sympathy of" opinion makers in Portugal "for the former Portuguese prime minister". Then comes the description of the relation of the company Odebrecht Portugal (which appears as the main actor) with two cases under investigation, the Monte Branco Operation (tax fraud and money laundering) and the BPN case (collapse of a bank due to mismanagement), under the title "Operation Mont Blanc and the BPN case". There is no reference in the text or in the infographics to political and ex-political actors, but only to companies and entrepreneurs whose motivations are tax evasion through money laundering.

The same news story, under the title "Operation Marquês and Armando Vara", describes the relationship of this former socialist leader and the Portuguese public bank (Caixa Geral de Depósitos) with the Lava Jato processes in Brazil and Marquês in Portugal. The infographics which accompany this report also elect, as central actor, the former politician and former administrator mentioned above. In the last subtitle of the same news, "TGV and Operation Marquês", there is a new mention to the Brazilian construction company Odebrecht, through its branch in Portugal (Bento Pedroso Construções), and to the Lena Group (contractor). Both were potential beneficiaries of public works concessions, namely for the construction of the high-speed rail (TGV). The infographics which accompany the text show the Brazilian construction company as a central actor, establishing relations with the consortiums in which it took part, with the presence of Lena Group and the mention of the relation with Operation Marquês. We emphasize the density of the bonds between actors (individual and collective) and the cohesion of the objectives, as well as the political and economic motivations presented in the story. It is a descriptive article, using a set of information in a hypotheticaldeductive way.

In the Brazilian site $61 . \mathrm{Com}^{10}$, the chosen news article is in the section "Politics", under the headline "Operation Lava Jato". The sub-title overlapps a photo of a building (suggesting the apartment being investigated in this operation which belonged to the ex-Brazilian President): "The connections of Lava Jato: Who are the suspects and what, according to PF (Federal Police), was the corruption and money laundering scheme which handled billions and involved Petrobras." Then, in a gray bar graph, other headlines are displayed on the right side: "What: Operation Lava Jato; When: Initiated by the Federal Police on March

\footnotetext{
${ }^{10}$ http://g1.globo.com/politica/operacao-lava-jato/infografico.html
} 
17". On the left side, the following headlines: "Suspicions - money laundering by individuals and corporations; payment of bribes to politicians; slush fund to finance allied government parties; corruption of public officials; tax evasion and deviation of public and Petrobras resources".

Going down the page, we can read: "How money was diverted in three steps: understand the scheme, according to the Federal Police and testimonials of rewarded whistleblowers". You can then activate a video which explains the corruption scheme, the people involved and the possible beneficiaries. The article has very little text and is predominantly graphic, with infographics and illustrations about actors (politicians and entrepreneurs, public and private companies), companies, informers, arrestees in the process by company, activity, etc. Finally, always very schematically, the article draws a "research timeline." The credits to the authors of the infographic appear at the end [Edition: Gustavo Miller (content); Leo Aragão (infographics) and Marcelo Brandt (Photography); Infographics: Karina Almeida and Roberta Jaworski; Developers: Fábio Rosa and Rogério Banquieri].

"Who kept what in Petrobrás: Investigation and testimonies indicate that parties controlled directories, according to the Federal Police". This is the headline of an infographic presented in the form of an organization chart which crosses four vertical columns and four horizontal columns. In the first horizontal column, the Administrations and the Parties to which they are linked are identified (Supply to PP, International to PMDB and Exploration plus Gas and Energy Services to the PT). In the second horizontal column are identified managers and directors as central actors, with names, photos and situation in the process: "House arrest", "Arrested", "Denies knowing the scheme" and "In freedom with restrictions". In the third horizontal column appear the names of the frontmen and their functions. They are not represented by photographs, which confers them less visibility. Finally, in the last column, the percentage of bribes charged is shown: $1 \%$ for the PP and the PMDB and $3 \%$ for the PT.

Figure 3: Representation of the Lava Jato case in the G1.com Portal

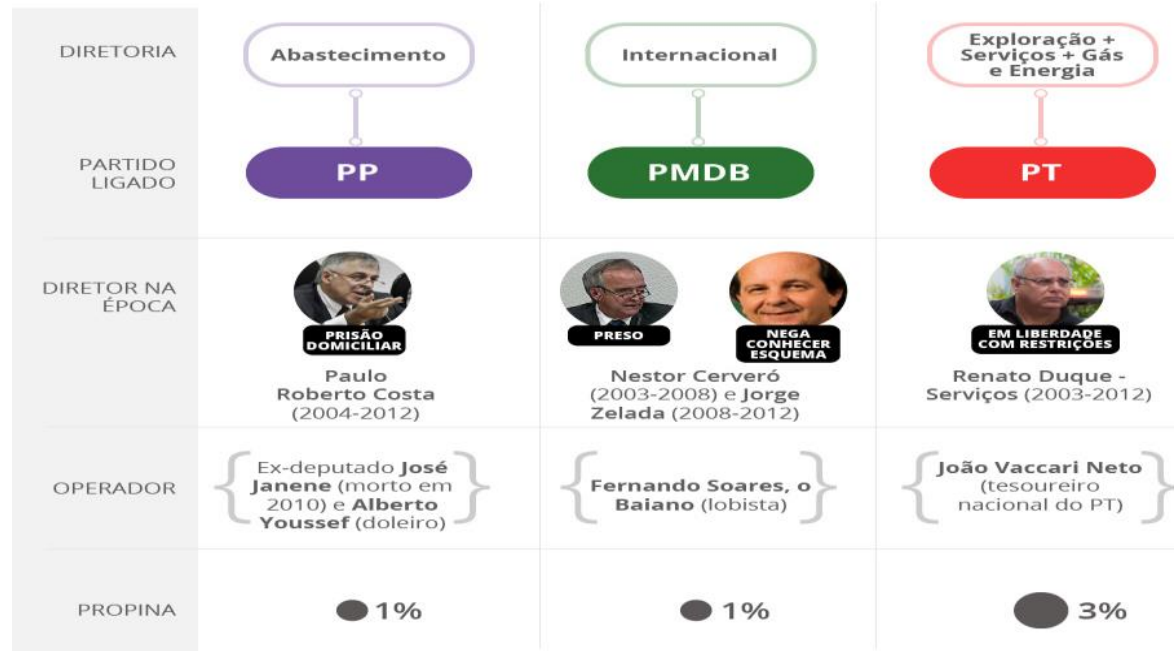

Under the subheading "Principal informers: money changer, former director of Petrobrás and entrepreneurs and suppliers of the state-owned company have made plea bargain agreements". All these actors are listed, with photos, activities, functions and links. This list is continued under the sub-subheadings: "Other informers: in all, more than 15 plea bargain agreements have been made with the Federal Public 
Prosecutor"; "Major contracts investigated: Refinery works in Brazil and purchase of Pasadena are on the radar of the Federal Police". This is followed by another infographic where the "Contract", the "Value of the Work", the "Contractors" involved and the "Possible leak" are identified. Next is reported "The situation of prisoners of Lava Jato until now: contractors' director, Petrobras directors and persons related to Youssef were taken to the PF". These arestees are identified by company, crime involvement, functions and legal situation. As we mentioned before, the news story ends with an illustration where the "Timeline of the investigation is drawn: The operation was triggered on March 17 (2014)". It describes the main facts, investigations and events of the Lava Jato process, accompanied by photographs of the actors involved.

The fourth article which we analyzed, the second from Brazil, was published on the internet page of the newspaper O Estado de São Paulo11 (Figure 4), in the "Infographics" section. It is entitled "The organogram of an Unprecedented Scandal," with the headline "See how a diversion scheme was set up to supply parties and politicians through a slush fund."

Figure 4: Representation of the Lava Jato case in O Estado de S. Paulo (March 2015)

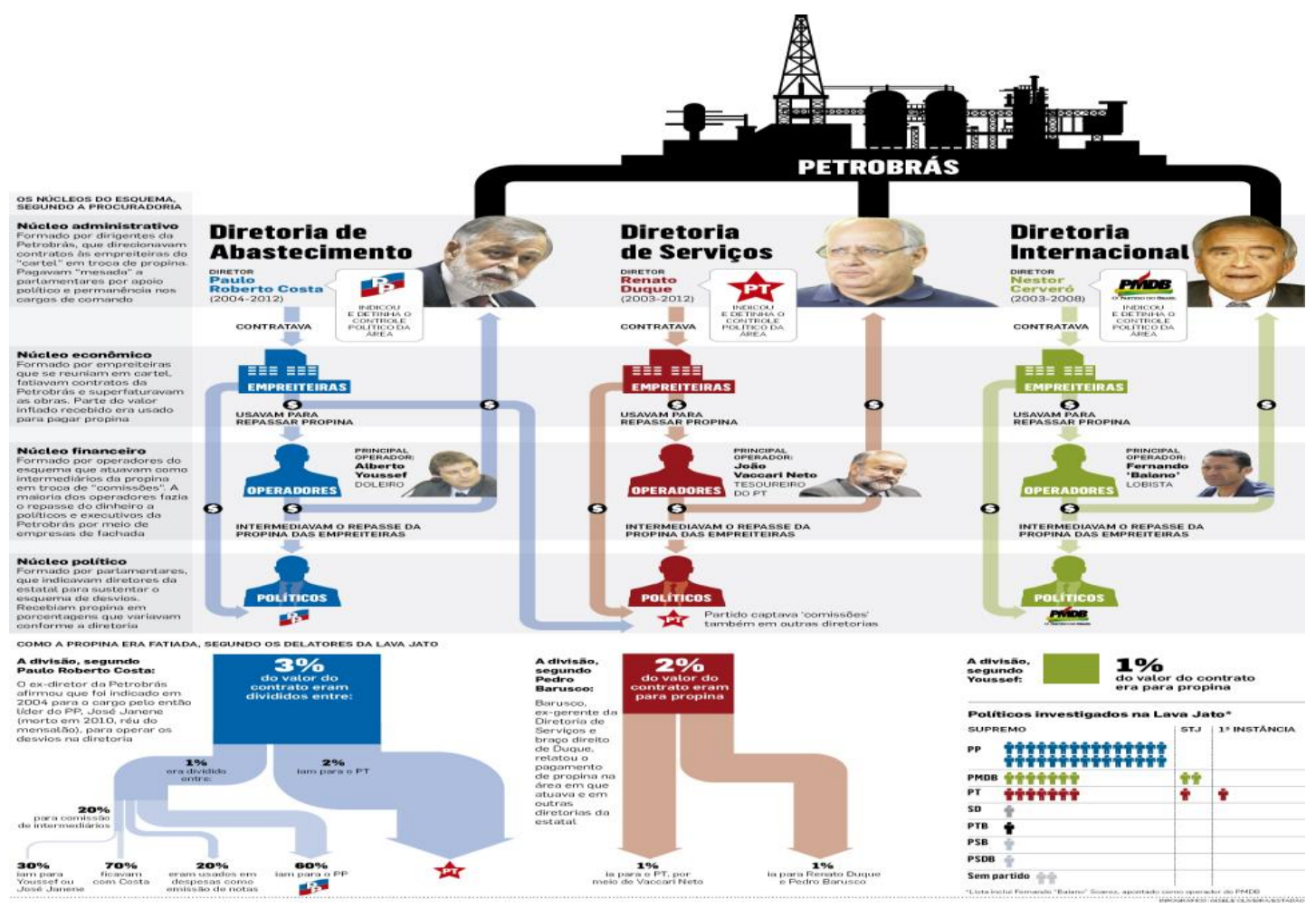

\footnotetext{
${ }^{11}$ http:/www.estadao.com.br/infograficos/politica,o-organograma-de-um-escandalo-sem-precedentes
} 
It is an infographic with a vertical column on the right entitled "The sectors of the scheme according to the Attorney General", subdivided into horizontal columns: "Administrative sector"; "Economic sector"; "Financial sector"; "Political sector"; "How the bribery was sliced, according to the Lava Jato whistleblowers." It is in this column and in these items that most of the information is found, and then placed in the form of network representation in the infographic. The description of the sectors reveals the modus operandi of the leaders, who "channeled contracts to the contractors of the cartel", the bribes paid to parliamentarians, the overinvoicing and the flow of the diverted money. In the last horizontal column we can still read the information about the division of the money provided by the informers: "The division according to Paulo Roberto Costa"; "The division according to Pedro Barusco"; "The division according to Youssef" and "Politicians Investigated in Lava Jato". The organogram presented has, as the central node, the Brazilian petroleum company Petrobrás, linked to three other actors, identified by name and photo. In the base of the infographics, the vertical column reveals the percentages obtained by the parties involved and their respective parties, as well as the investigations in progress.

Through this network organization, which links politicians to companies (contractors), it is possible to perceive the functions of these actors (individual and collective, public and private), the hierarchy of command, the motivations of the crime and how the benefits were distributed, particularly the funding of political parties. The link between actors and their motivations are mapped assertively and based on factual information from prosecution investigations, whistleblowing and court proceedings.

The latest news item which we analyzed was published in Folha $8^{12}$, an online newspaper, which presents itself as "More Than a Newspaper: The Liberty". Its director is William Tonet and its assistant director Orlando Castro. The article was published on January 12, 2015 in "Destaque (Spotlight): Lusofonia" with the title "Mensalão: The Luso-Angolan-Brazilian network". The lead, under the infograph, is: "Miguel Horta e Costa, the former president of Portugal Telecom, current director of BESI and president of the LusoBrazilian Foundation, was charged in a lawsuit which investigates corruption in international trade". The subheadings are: "Dirceu ${ }^{13}$ close to Relvas ${ }^{14}$ and Angolan interests"; "The Mensalão arrives in Angola"; "The Portuguese-Brazilian network of the José Eduardo dos Santos Foundation". It is signed by Jorge Costa and was initially published on the portal Esquerda Net. According to these subheadings and to the investigations carried out in Brazil by one of the detainees in the Mensalão case, the text lists the links between Portuguese politicians and companies (Banco BES and Portugal Telecom, PT), for funding the Workers' Party (PT) of former President Lula da Silva. The article also describes the interests of some of those involved - politicians and former CEO of large Portuguese, Brazilian and Angolan companies - in the expansion of these companies to the Lusophone Space. It highlights the privatization of the Portuguese airline company (TAP), and its political intermediaries in Brazil. Angola is cited as part of the triangulation of illegal financial flows, which would pass through Lisbon (Banco Rural Europa), the Cayman Islands and Cape Verde (International Trust Bank, Banco Fiduciário Internacional).

In the infographics which accompany the text (Figure 5), the newspaper emphasizes three actors (with

\footnotetext{
12 http://jornalf8.net/2015/mensalao-rede-luso-angolana-brasileira/

${ }^{13}$ Dirceu, José (2003-2005) - Former Brazilian Presidential Chief of Staff of President Lula da Silva (Workers' Party,PT 2003-2011).

${ }_{14}$ Relvas, Miguel (2011-2013) - Minister of State for Parliamentary affairs of the PSD (Social Democratic Party) government (2011-2015).
} 
photographs and names) who constitute nodes: former advisor to former Brazilian President Lula da Silva, José Dirceu, the president of Angola, José Eduardo dos Santos and a former Portuguese minister of a socialdemocratic government, Miguel Relvas. Eleven other individual actors (politicians, ex-politicians and entrepreneurs) and twelve companies are identified by photographs or logos. The Mensalão case, originated in Brazil, is represented as a transnational scandal, with tentacles in different geographies and contexts of the Portuguese-speaking world, involving companies and banking institutions of the Lusophone Space.

Figure 5: Representation of the Mensalão case in Angola in the newspaper Folha 8 (January 2015)

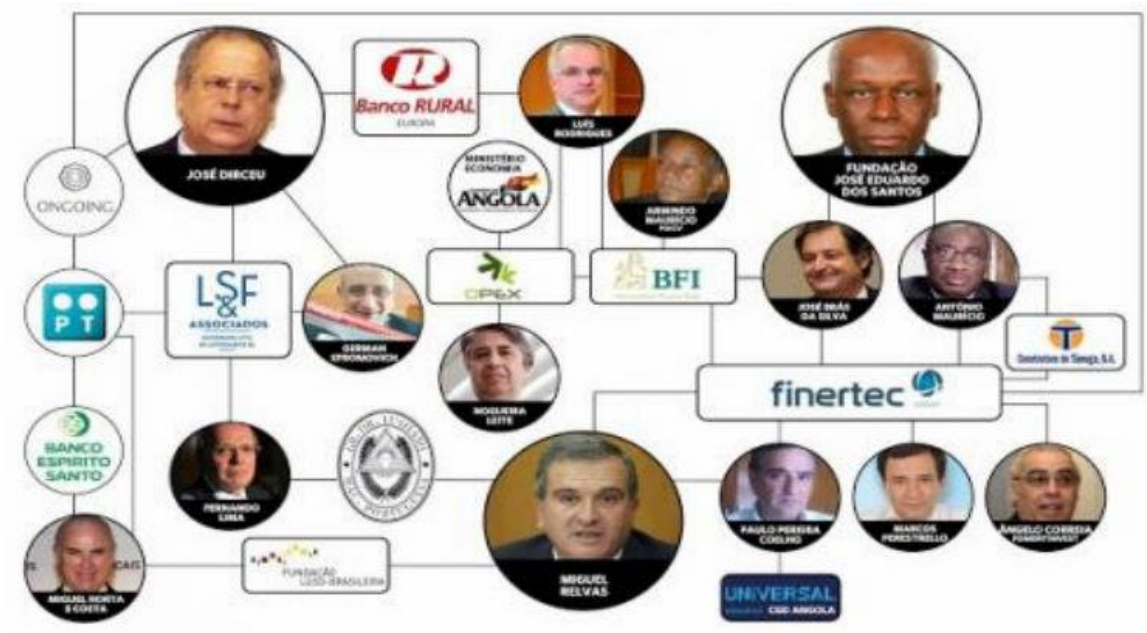

The article highlights the action of Portugal Telecom's former president, Miguel Horta e Costa, who may have been the link with the Mensalão in Portugal, through contacts with former PT Minister Jose Dirceu. This relationship does not have the same prominence in infographics, where the node represented by that actor is secondary. The role of this CEO, a former president of Portugal Telecom with privileged contacts with Banco Espírito Santo (BES), would be to raise funds for the Workers' Party (PT) in Portugal, during the Lula da Silva administration. In return, members of the Brazilian government would work to promote Portuguese business in Brazil.

Figure 5 also highlights the role of the Luso-Brazilian Foundation (FLB), which in 2013 was chaired by the same former CEO of PT, as a node for Portuguese, Brazilian and Angolan interests. The text raises suspicions when it states that Portugal Telecom became a Portuguese-Brazilian company exactly during the period in which two former CEOs of PT, which were part of the corporate bodies of the same Foundation, held the presidency of the telecommunications company. The infographics also show the connections of representatives of Angolan interests, former ex-ministers and politicians, who took up positions at the LusoBrazilian Foundation. This is the case of two chairmen of Banco Comercial Português (BCP), one appointed by the Angolan oil company Sonangol and the other with links to Finertec, an Angolan company connected to the José Eduardo dos Santos Foundation.

The graphical representation has discrepancies with the text, namely the identification of the main actor and the connections (motivations) of the other actors. We can also observe that the representation of the 
network of sociability and interests extrapolates the information contained in the text, besides not being detailed, nor mentioning the dates of the events, nor the functions of the actors.

\section{Conclusions}

In recent decades, countries such as Portugal and Brazil have witnessed a growing media exposure of corruption cases. Angola, given the prevailing authoritarian political system, does not have a sufficiently independent press which can investigate and publicize these phenomena with the same intensity. However, we emphasize that corruption, as economists, politicians and academics from various quarters refer, is not characteristic of countries in the South only, either in the geographical south of Europe or in the political / economic South. It also exists in the North, as Stiglitz (2012) points out, corruption is only more sophisticated in the countries of the North, where the American way of corruption prevails, characterized by games of influence and pressure, political and economic, prior to decision-making. Surveys such as the "Transparency International Global Corruption Barometer: Europe and Central Asia" show that the indicators of perceived corruption by citizens come mainly from media content. Three groups of professionals are identified by the respondents as more susceptible to corruption, perceived by the following order: managers and executives, mayors and members of parliament.

Based on the description and analysis of the five news items and their infographics, we can see that the texts build networks of relationships and sociability between actors and institutions in Portugal and Brazil, but also in African countries which speak Portuguese, such as Angola and Cape Verde. Mainly, these networks of relationships involve political actors and public and private institutions. The relations are transversal to political parties, social statutes and national interests, since they bring together actors and institutions originating from different social strata, ideological quarters and nationalities. The news articles emphasize the motivations, not only political and economic, of the agents involved, as well as the connections and the density of the ties that bind the participants. In the descriptions, we can map the political and business connections of each country and between countries of the Lusophone space, particularly the interrelations which connect the high representatives of democracy and the business sectors of the construction and telecommunications. However, we perceive that the exposure of actors and political institutions is much more pronounced than corporate groups and their CEOs.

The news use network infographics to make the "information" more visible, but also to give more visibility to the actors - represented as nodes and recognized by their photographs - and corporate groups. The infographics have a great power of mediatization, in the sense that the graphics and the images acquire a sense of autonomy from the events. At the same time, it tends to consolidate public knowledge about the subject and the actors. In this way, the conjugation between the news story and the infographics constitutes a mediatic logic which accompanies some of the assumptions of the European academics of Mediatization Theories (Stromback, 2011, Hepp, 2012, Couldry and Hepp, 2013, Levingstone and Lunt, 2014). From a comparative perspective, it should mentioned that the two Brazilian news articles give more importance to infographics than to texts, using the former to convey structured and organized information. In both Portuguese news articles, the correspondence between the text and the representation in infographics is partial. This discrepancy is accentuated in the article published in the Angolan newspaper. In the Portuguese 
case, the substance of the information lies in the written text, while in the Brazilian case the graphic representation consubstantiate the information. In the article published in the Angolan newspaper there are noticeable discrepancies between the substance of the news and its graphic representation.

As we have pointed out, the infographics represent networks of multinational interests sustained by public and private agents. These actors interrelate in the Portuguese-speaking world, creating complex networks of sociabilities and political and economic negotiations. The network configuration of these "Portuguesespeaking sociabilities" gives visibility to the high representatives of democracy in these countries, as well as the CEO of large companies. It also exposes the conflicts of interests between agents and institutions, as well as the possible influence peddling within the economic diplomacy of the country involved. The mapping carried out in the texts and infographics shows, for example, how "elites" transit the same spaces and maintain conflicts of power around valuable and scarce resources and how, in many cases, economic diplomacy leads to misunderstandings and overlapping of public and private interests.

Despite the adoption of legally or morally reprehensible practices, the texts and the infographics indicate, however, that these elites aimed at structuring business alternatives to hegemonic globalization, which are controlled by companies and capitals outside the Lusophony space. The aim of the actors, as revealed in at least some of the consequences of the cases reported and analyzed, independently of the illicit processes and procedures, seems to be to widen the scope of action of the national companies of each country, reinforcing the potential of the Lusophone Space market.

We also note the different relationship between media and justice in Portugal and Brazil, being clear that journalistic coverage in Brazil relies on access to legal proceedings. In this sense, the news lists illicit acts, situations and scenarios where corruption occurs, as well as the name and data of large numbers of defendants and their legal situation. In Portugal, where "secrecy of justice" obeys stricter rules, news information is less precise and, for this reason, we find that it has a less assertive, more hypothesis-based discourse.

In the course of this exploratory approach, innumerable issues have arisen, not only about corruption and the complex way it presents itself, but also about the epistemological challenges, particularly methodological ones, concerning networks of sociability. We therefore consider that these are challenges that must be faced by the investigation of these phenomena, in the context of the social sciences and the studies on mediatization.

\section{References}

Blankenburg, E. (2002). From political clientelism to outrighy corruption -The rise of the scandal industry, Political corruption in transition: a sceptic's handbook. CEU Press, Central European University Press, 149-165.

Couldry, N., Hepp, A. (2013). Conceptualizing Mediatization: Contexts, Traditions, Arguments, Communication Theory, v. 23, (3), 191-202.

Cunha, I. F., Serrano, E. (2014). Cobertura Jornalística da Corrupção Política: sistemas políticos, sistemas mediáticos e enquadramentos jurídicos. Lisboa: Aletheia. 
Davis, S., Strauhbaar, J., Ferin, I. (2016). The construction of a transnational Lusophone media space: a historiographic analysis. Popular Communication Journal: The International Journal of Media and Culture, vol 14, (4), p. 212-223.

Duarte, F., Quandt, C., Souza, Q. (2008). O tempo das redes. São Paulo: Editora Perspetivas.

Freire, A. (2016). Eleições e sistemas eleitorais no século XX Português: uma perspectiva histórica comparativa. Lisboa: Ed. Colibri.

Gray, J., Chambers, L., Bounegru, L. (2012). The Data Journalism Handbook. Retrieved from https://openzazu.files.wordpress.com/2012/08/the-data-journalism-handbook-gnv64.pdf

Hallin, D., Mancini, P. (2012). Comparing Media Systems Beyond the Western World. Cambridge: Cambridge University Press.

Hepp, A. (2012). Mediatization and the "Molding Forces" of the Media. Communications, v. 37, 1-28.

Johnston, M. (2005). Syndromes of corruption: wealth, power and democracy. Cambridge: Cambridge University Press.

Lemieux, V., Ouimet, M. (2008). Análise estrutural das redes sociais. Lisboa: Instituto Piaget.

Levingstone, S. (2012). Challenges to Comparative research in globalization media landscape, Handbock of Comparative Communication Research. ICA Handbook Series. New York: Routledge.

Levingstone, S., Lunt, P. (2014). Mediatization: an emerging paradigm for media and communication studies, Handbook of Communication Science. Berlin: De Gruyter Mouton, 703-724.

Merclé, P. (2004). Sociologie des réseaux sociaux. Paris: La Decouverte.

Moisés, J. A. (2012). Democracia e confiança: porque os cidadãos desconfiam das instituições públicas. São Paulo: EDUSP.

Stiglitz, J. (2012). The Price of Inequality. New York: Norton.

Strauhbaar, J. (1991). Beyond media imperialism: Assymetrical interdependence and cultural proximity. Critical Studies in media communication, pp. 35-39.

Stromback, J. (2008). Four Phases of Mediatization: an Analysis of the Mediatization of Politics. Press Politics, v.13, (3), p. 228-246.

Stromback, J. (2011). Mediatization and perceptions of the Media's Political Influence. Journalism Studies, v.12, p. 423-439.

Zaharna, R. S., Arsenault, A., Fisher, A. (2013). Relational, Networked and Collaborative Approaches to Public Diplomacy: The Connective Mindshift. London: Routledge. 